\title{
Micro-SME Characterization From Financial Statements
}

Guillermo Ceballos-Santamaría, University of Castilla-La Mancha, Spain Juan-José Villanueva-Álvaro, University of Castilla-La Mancha, Spain José Mondéjar-Jiménez, Ph.D., University of Castilla-La Mancha, Spain

\begin{abstract}
In recent years, small businesses have created interest and research, because they represent the majority of the business fabric and account for over seventy per cent of jobs in developed countries. Governments of these countries share a general interest in knowing about Small and Medium-Sized Enterprises (SME). Based on this premise, the approach of this study is to characterize micro-SMEs in the province of Cuenca, Spain, by analysis of financial statements, specifically analyzing their structure in financial terms by use of univariate and multivariate statistical techniques allowing this kind of business in the province of Cuenca to be identified. The information used comes from the databases of SABI (Iberian Financial Statement Analysis Systems), DIRCE (Central Business Directory and CamerData, the database of the Chambers of Commerce. The statistical analysis is centered on a classic modal of exploratory factor analysis, and finally the main results arising from the study are presented.
\end{abstract}

Keywords: Micro-SME; Factor Analysis; Accounting Ratios

\section{INTRODUCTION}

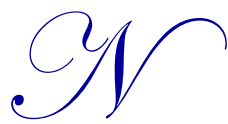

umerous empirical studies have tried to verify the extent to which enterprises' financial behavior corresponds to that predicted by existing theories related with capital structure (Modigliani and Miller, 1958; Jensen and Meckling, 1976; Miller, 19977 and Myers and Majluf, 1994). The purpose of these studies was to find out whether an optimum capital structure existed, or to put it another way, whether a financial structure could be identified with a debt level more appropriate than others.

In some cases, theories which are valid for large enterprises do not adapt to the peculiarities of SMEs, because of the great differences between them. So, as a result of the flaws in capital markets, SMEs (particularly smaller ones) face a problem of credit rationing which affects both their capital structure and the cost of outside resources. According to Maroto (1996), these flaws give rise to the predominance of two theoretical focal points: one for large enterprises and anther for SMEs. The studies of Boedo and Calvo (1997), Melle (2001), Sogrob and Lopéz (2003), Rodriguez (2003) and Cardone and Cassasola (2004) highlight these differences by examining the case of Spanish SMEs and comparing it with studies of large enterprises in the Spanish market, such as those proposed by Martín (2000), Arrondo (2002) and García and Martínez (2003). This is why separation needs to be made between these types of company when their structure is analyzed.

First, as their name indicates, these are small enterprises with less share capital and a weaker financial and economic structure. Because of this, their capital market access is different from that of large enterprises and for the specific case of Spanish SMEs and even more so for those in the province of Cuenca, Spain, is limited to selffinance and dependence on banks. The growth in the business fabric in our province has maintained a clear upward trend in the creation of enterprises, most of them the MicroSMEs subject to analysis in this study.

The study is intended to provide characterization of Cuenca's micro-enterprises taking as starting point the information about companies from the financial statements ((Balance Sheet, Profit and Loss Account and Annual Report) they deposit in the Trade Register every year. This primary information and the information derived from it 
(accounting ratios) is the economic source available at the moment. With this information, the study intends to argue the hypothesis that we are going to find a specific business structure that should match the previously described characteristics. Beginning with the reality that most enterprises in Cuenca are micro-SMEs, it seems reasonable to think that we are looking at enterprises which organize their idiosyncrasy more with the aim of pure survival than following orthodox market rules, numerous micro-enterprises with low turnover who control a very limited part of the market.

\section{STUDY METHODOLOGY AND OBJECTIVES}

Article 2 of the Official Journal of the European Communities (OJEC 361-2003) establishes the effective and financial limits of enterprises like this: "The category of micro-enterprises, small and medium-sized enterprises (SME) consists of companies which employ fewer than 250 people and whose annual turnover does not exceed 50 million euros or whose annual balance sheet total is no more than 43 million euros. In the category of SMEs, a small enterprise is defined as one which employs fewer than 50 people and whose annual turnover does not exceed 50 million euros or whose annual balance sheet total is no more than 10 million euros. In the category of SMEs, a micro-enterprise is defined as one which employs fewer than 10 people and whose annual turnover or annual balance sheet total is no more than 2 million euros.

To obtain the sample, first, the geographical scope under analysis was decided, selecting the province of Cuenca, of all the companies in the database, 3,751 correspond to the province of Cuenca.

With the province of Cuenca defined as the area being studied, only enterprises with accounting information available for the year 2006 were selected, delimiting the sample size. Company size was then added to the search criteria, using the definition of micro-enterprise used by the Official Journal of the European Communities related with number of employees, turnover and total assets, giving a final sample of 1,354 enterprises in the geographic location of the province of Cuenca complying with the classification criteria of micro-enterprises (the most frequent kind of business in the province) for which accounting information for 2006 is available.

To carry out the empirical part, the main financial and economic ratios available were used. The ratios are obtained from the balance sheet and the profit $\&$ loss account and provide financial and economic information about the different enterprises analyzed.

\section{EMPIRICAL FINDINGS}

We often have a very large number of variables to measure a particular reality. Factor analysis is a data reduction technique, i.e., from that large number of variables, it obtains a smaller number of explanatory elements, the factors, allowing this reality to be explained in a simpler way. Evidently, these factors need to be obtained and interpreted beginning with the initial variables, and it is also true that the model will lose explanatory power in the process. The key is to gain facility in order to interpret the reality with the lowest possible cost in terms of information loss and statistical errors committed (Ferrán, 1996).

Compared with other techniques, factor analysis has the advantage of introducing a larger number of variables and their explanation with fewer factors. If this were so, we would have the advantage, for example, that other multivariate techniques the algorithms of which can become very slow when many variables are used, such as cluster analysis, would be simpler to use. So evidently with this objective we are not trying to find relations of dependence between some variables and others, but possible interdependence between variables. We have no theoretical base to tell us what the components of the "characterization of the micro-SMEs" are, therefore, this is not a confirmatory factor analysis which would need to be carried out using systems of structural equations. Neither do we want to establish groups of enterprises (for which we would use cluster analysis), but to group variables into factors. By this logic, exploratory factor analysis is the right technique to use.

The method we are going to use to extract the factors is principal component analysis, which is suitable when the intention is to summarize the largest possible part of the initial information (variance) in the lowest number of possible factors, which we can say is the most common use of factor analysis. The criterion for determining the number of factors that should be extracted, by default the criterion of eigenvalues greater than one 
used by SPSS recommends a number of between 20 and 50 variables, therefore we are at the bottom end for our study, so we should take the proportion of total variance explained and the screen test into account, although statistically values above $80-90 \%$ of explained variance are recommendable, in the social sciences, working with real data, use of the $50-60 \%$ criterion is customary.

Each factor is a linear combination of various variables, and to understand its meaning, i.e., interpret it, which variables contribute most to its explanation must be seen. One very important tool aiding the interpretation of factors is their rotation, meaning that one of the original values will have a correlation as close as possible to 1 with one of the factors and correlations close to 0 with the other factors.

Table 1: Total explained variance

\begin{tabular}{|c|c|c|c|}
\hline & \multicolumn{2}{|c|}{ Initial eigenvalues } \\
\cline { 2 - 4 } & Total & $\mathbf{1 4 , 1 5 1}$ & $\mathbf{1 4 , 1 5 1}$ \\
\hline $\mathbf{1}$ & $\mathbf{3 , 1 1 3}$ & $\mathbf{1 0 , 5 9 0}$ accumulated \\
\hline $\mathbf{3}$ & $\mathbf{2 , 3 3 0}$ & $\mathbf{1 0 , 0 3 9}, \mathbf{3 4 1}$ \\
\hline $\mathbf{4}$ & $\mathbf{2 , 2 0 9}$ & $\mathbf{7 , 7 0 2}$ & $\mathbf{4 2 , 4 8 2}$ \\
\hline $\mathbf{5}$ & $\mathbf{1 , 6 9 4}$ & $\mathbf{6 , 9 0 2}$ & $\mathbf{4 9 , 3 8 4}$ \\
\hline $\mathbf{6}$ & $\mathbf{1 , 5 1 8}$ & $\mathbf{6 , 4 8 5}$ & $\mathbf{5 5 , 8 6 9}$ \\
\hline 7 & $\mathbf{1 , 4 2 7}$ & 5,774 & 66,265 \\
\hline 8 & 1,270 & 4,622 & 70,764 \\
\hline 9 & 1,017 & 4,500 & 75,143 \\
\hline 10 &, 990 & 4,379 & 78,995 \\
\hline 11 &, 963 & 3,852 & 82,738 \\
\hline 12 &, 848 & 3,743 & 86,288 \\
\hline 13 &, 823 & 3,550 & 89,195 \\
\hline 14 &, 781 & 2,907 & 91,933 \\
\hline 15 &, 639 & 2,738 & 94,167 \\
\hline 17 &, 602 & 2,234 & 96,289 \\
\hline 18 &, 491 & 2,122 & 97,998 \\
\hline 19 &, 467 & 1,709 & 99,108 \\
\hline 21 &, 376 & 1,109 & 99,808 \\
\hline
\end{tabular}

So, there being more variables than common factors, every factor will have a high correlation with a group of variables and low correlation with others. By examination of the characteristics of the variables of a group associated with a particular factor common traits can be found allowing the factor to be identified and given a denomination responding to these common traits, i.e., interpreted (Table 2).

Having loaded the factors (Table 2), we can make the following interpretation of the retained factors with a proportion of explained variance of around 56\%:

- Factor 1: Overall position of the enterprise (Strength). This factor is strongly related to the variables Revenue and Assets, and to a lesser degree to Own Funds, Number of Employees and Cash Flow.

- Factor 2: External finance. In this case related with Financial Costs and Short-Term Credit and with a weak and inverse relationship with asset rotation.

- Factor 3: Economic strength. Based on the variables Profit/Loss, Economic Profitability and Own Funds in relation with liabilities. Also with a strong, though logically inverse relationship with the variable Indebtedness.

- $\quad$ Factor 4: Liquid assets needed. This factor is related with the variables Working Capital and Working Capital Requirements and is also related with another three variables, but with factor loads below 0.4.

- Factor 5: Cash-flow requirement. Related with the payment capacity of micro-SMEs and related with the variables Liquidity, Liquidity Ratio and Cash Flow.

- $\quad$ Factor 6: Business Growth. This factor is related with growth in sales and growth in the Added Value of the enterprises studied. 
Table 2: Matrix of rotated components

\begin{tabular}{|c|c|c|c|c|c|c|}
\hline & \multicolumn{6}{|c|}{ Componente } \\
\hline & 1 & 2 & 3 & 4 & 5 & 6 \\
\hline Ingresos & ,707 & & & & & \\
\hline Resultado & & &, 629 & & & \\
\hline Activo & ,866 & & & & & \\
\hline FPropios &, 543 & &, 422 & ,333 & & \\
\hline Renteco & & &, 734 & & & \\
\hline Rentfin & & & & & & \\
\hline Liquidez & & & & & ,759 & \\
\hline Endeuda & & &,- 753 & & & \\
\hline Empleados & ,603 & & & & & \\
\hline CreVentas & & & & & & ,769 \\
\hline Ractivos & &,- 304 & & & & \\
\hline Product & & & & & & \\
\hline CreVA & & & & & & ,811 \\
\hline GasFinan & & ,930 & & & & \\
\hline FM & & & & ,804 & & \\
\hline NFM & & & & ,957 & & \\
\hline Tesoreria & 544 & & &,- 310 &, 415 & \\
\hline Equilibrio & & & & 370 & & \\
\hline CreditoC & & ,906 & & & & \\
\hline FPsobreP & & & ,484 & & &,- 367 \\
\hline Devolucion & &, 574 & & & & \\
\hline LiquidezI & & & & &, 825 & \\
\hline
\end{tabular}

\section{CONCLUSIONS}

The aim of this study is to examine the situation of micro-enterprises in Cuenca in their economic context in their province and region. The first conclusion we might draw is the interest knowledge of the small business arouses. This interest is seen in the proliferation of studies dealing with this subject in recent years. Both public and private institutions need know as well as possible about the enterprises that represent an important part of the gross domestic product and employment throughout Spain.

This study was intended to obtain results quickly and easily, but with the least possible error, for subsequent analysis. We wanted to analyze the situation of micro-SMEs in the province of Cuenca in two ways. Firstly, analyzing the basic descriptive statistics of their financial statements, and secondly, by factor analysis, a statistical technique that allows all the variables in the financial statements to be resumed in just six factors offering reliable information on the profit \& loss, liquidity and share capital situation of businesses.

Looking at how they obtain finance, the problems small enterprises have in separating business capital from the personal money of their owners are seen. It is customary for owners to put their own money in to the business (or take it out). This is because, although these are entities which in principle have their own, independent, legal status, their owners - often very few people and very often a single person - behave like businessmen-workers rather than capitalist owners.

Furthermore, it is well known that the banking sector offers this kind of enterprise few financial products, limited to loans, credit policies and leasing operations. Operations which more often than not, if not always, need to be personally guaranteed by the possessions of the owners.

The study also shows that micro-SMEs have a specific financial structure. The structure of their own funds shows the practical non-existence of distribution of profits among partners and the high level of reserves generated. This characteristic, as well as showing a customary form of financing in micro-SMEs, shows the extent to which business decisions are conditioned by economic legislation. As we have said, to enterprise owners dividend distribution means double taxation, so they prefer to take out their money as wages (using their twin condition of shareholder and worker) rather than share profits. 
If we examine the market share of this kind of enterprise, the study corroborates the results we expected to obtain. There are many enterprises controlling a very low market share. One proof of this is that the average turnover figure for Cuenca micro-SMEs is well below the minimum two million euros set by the European Union for a company to be considered a micro-enterprise. These figures reflect the limitation of the selling area to local markets, neighboring provinces at most.

\section{AUTHOR INFORMATION}

Guillermo Ceballos-Santamaria, Degree in Business Administration by University of Valencia. Degree in Advanced Studies in Economic by University of Castilla-La Mancha. Assistant Professor in Economic Department. Faculty of Social Sciences of Cuenca. University of Castilla-La Mancha (Spain). Research Interest: Economic and tourism. Phone +34 902204 100; Fax +34 902204 130; E-mail: Guillermo.Ceballos@uclm.es (Corresponding author)

Juan-José Villanueva-Álvaro, Degree in Business Administration by University of Valencia. Assistant Professor in Economic Department. Faculty of Social Sciences of Cuenca. University of Castilla-La Mancha (Spain). Research Interest: Economic and tourism. Phone +34 $902 \quad 204$ 100; Fax +34 902204 130; E-mail: $\underline{\text { JuanJose.Villanueva@uclm.es }}$

José Mondéjar-Jiménez, European $\mathrm{PhD}$ in Economics and Degree in Business Administration by University of Castilla-La Mancha. Associate Professor in Statistics at Statistics Department. Faculty of Social Sciences of Cuenca. University of Castilla-La Mancha (Spain). Research Interest: regional analysis, educational and tourism. Phone +34 902204 100; Fax +34 902204 130; E-mail: Jose.Mondejar@uclm.es

\section{REFERENCES}

1. Arrondo, R. (2002): "La valoración por el mercado de capitales español de la decisión de ampliar capital: efectos informativos y costes de agencia". Revista europea de dirección y economía de la empresa, vol. 11, $\mathrm{n}^{\circ}$ 3, pp. 35-46.

2. Boedo, L. and Calvo, A. (1997): “Un modelo de síntesis de los factores que determinan la estructura óptima de las pymes", Revista europea de dirección y economía de la empresa, vol. 6, nº 1, pp. 107-124.

3. Cardone, C. y Cassasola, M. (2004): "Comportamiento financiero de la Pyme española: una visión desde la teoría del orden de preferencias", XII foro de finanzas de Barcelona.

4. Comisión Europea (2003): Recomendación de la Comisión de 6 de mayo de 2003 sobre la definición de microempresas, pequeñas y medianas empresas. Diario Oficial de las Comunidades Europeas, 20 de mayo, pp. 124/36-41.

5. $\quad$ Ferrán, M. (1996): SPSS para Windows. Programación y análisis estadístico. McGraw-Hill. Madrid.

6. García, P. and Martínez, P. (2003): "La tesorería en la empresa y sus determinantes". Documento de Trabajo WP-EC 2003-19, Facultad de economía y empresa. Universidad de Murcia.

7. Hispalink (2008): "HISPADAT. Banco de datos" (Madrid: Instituto L.R. Klein y Consejo Superior de Cámaras de Comercio, Industria y Navegación de España).

8. Instituto Nacional de Estadística (2008b): Directorio Central de Empresas DIRCE. Disponible en www.ine.es

9. Jensen, M. and Meckling, W. (1976): "Theory of the firm: managerial behaviour, agency costs and ownership structure". Journal of financial economics, 3, pp. 305-360.

10. Maroto, J.A. (1996): "Estructura financiera y crecimiento de las pymes". Economía industrial, vol. 310, no 4, pp. $29-40$.

11. Melle, M. (2001): “Características diferenciales de la financiación entre las pymes y las grandes empresas españolas". Papeles de Economía Española, 89-90, pp. 140-159.

12. Miller, M. (1977): "Bedt and taxes". Journal of finance, vol. XXXII, $\mathrm{n}^{\circ} 2$ mayo, pp. 261-275.

13. Modigliani, F. and Miller, M. (1958): "The cost of capital corporation finance and the theory of investment”. The American Economic Review, vol. XLVIII, no 3 junio, pp. 261-297.

14. Myers, S. and Majluf, N. (1984): "Corporate financing and investment decisions when firms have information investors do not have". Journal of Economic of Finance, 13, pp. 187-221. 
15. Rodríguez, O. (2005): "El crédito comercial en las PYMES canarias desde una perspectiva multivariante". Estudios de Economía Aplicada, vol. 23, no 3 (diciembre), pp. 773-816.

16. Sogorb, F and López, J. (2003): Pecking order versus trade off: an empirical approach to the small and médium Enterprise capital structure. Universidad Cardenal Herrera CEU y Universitat de Valencia. 